\title{
CHARACTERIZATION OF WHEAT VARIETY ADAPTED TO MUGAMBA ECOLOGICAL CONDITIONS IN BURUNDI
}

\author{
Bandushubwenge Denis*1 And Kwizera Chantal ${ }^{2}$ \\ ${ }^{1}$ University Of Burundi, Faculty Of Agriculture And Bio Engineering, Department Of Vegetal Productions Sciences, \\ B.p 2940 Bujumbura, Burundi \\ ${ }^{2}$ University Of Burundi, Faculty Of Agriculture And Bio Engineering, Department Of Environment Sciences And \\ Technologies, B.p 2940 Bujumbura, Burundi
}

https://doi.org/10.35410/IJAEB.2021.5622

\begin{abstract}
Wheat is one of the three important cereals which contains more protein and helps in preventing childhood asthma, protecting the body from coronary diseases. However wheat is very sensitive to climate change. Although it can be grown in many areas with different weather, the yield penalty is usually due to different environmental stresses that reduce yield potential. Some researchers highlighted decreased wheat growth and yield due to higher temperatures which leads to water stress in plant cells resulting in reduced crop growth, development and yield, whence this study has been carried out in cold region of mugamba to improve wheat yield and yield parameters through Characterization of adapted variety. Results of the study showed 21SAWYT338 variety as the most adapted variety in the region. It showed improved plant height and yield parameters. Moreover, this variety 21SAWYT338 has recorded an ealier maturity date which is valuable for household especially during the food lean season where they can sell a part of the haverst to buy supplement food nutrition leading to improved food security. This study suggested 21SAWYT338 variety as the most adapted variety that can be recommended to the farmers of the region.
\end{abstract}

Keywords: Six Wheat varieties, Growth and production parameters, wheat Yield and Mugamba region.

\section{INTRODUCTION}

Wheat is an economically important crop cultivated worldwide ${ }^{[1-2]}$. It ranks as the second most important food after rice, and is the most widely cultivated cereal in the world. It is one of the central pillars of food security, supplying $20 \%$ of total calories and a similar portion of total protein to the world's population ${ }^{[3]}$. Wheat is one of three cereals (together with rice and corn) which are the most important food sources for people, and whose total global consumption accounts for over $90 \%$ of total cereal consumption ${ }^{[4-5]}$. Wheat seed represent an important source of food and energy and is involved in the determination of bread-making quality ${ }^{[6]}$.It contains more protein than other cereal and has a relatively high content of niacin and thiamine ${ }^{[7]}$. It is basically concerned in providing Glutin, a characteristic substance, which is very essential for bakers. Furthermore, wheat contributes $60 \%$ of the overall caloric need and food 
protein for the mankind ${ }^{[8]}$.It is one of the most versatile grains when it comes to nutritional value and health. It provides more proteins and calories to the global population than any other agricultural food ${ }^{[2-7-9]}$. It has major health benefits such as controlling obesity, improving the metabolism in the body, preventing type 2 diabetes, reducing chronic inflammation, preventing gallstones, preventing breast cancer and promoting gastro-intestinal health in women ${ }^{[10]}$. Furthermore, wheat helps in preventing childhood asthma, protecting the body from coronary diseases, relieving postmenopausal symptoms and preventing heart attacks. From literatures, including wheat in the diet regularlycan benefit from all the nutrients, it also offers and prevent the occurrence of a multitude of ailments. However wheat is very sensitive to climate change. Although it can be grown in many areas with different weather, elevation, or soil properties, the yield penalty is usually due to different environmental stresses that reduce yield potential by $69.1 \%{ }^{[12]}$. Some researchers highlighted drought as a key stress that constrains wheat production on about $6.5 \times 10^{7} \mathrm{hm}^{2}$ of land worldwide ${ }^{[13]}$ and reduces yield by up to $50 \%{ }^{[14]}$, while others reported decreased wheat growth and yield due to higher temperatures ${ }^{[15]}$. Similarly, Senthold et al.( 2015) highlited decreased wheat yield due to increased temperature [16], whereas Modarresi et al. (2010)reported a reducedwheat grain yield and kernel weight due to high temperature ${ }^{[17]}$. All this shows the sensitivity of wheat to higher temperature which leads to water stress in plant cells resulting in reduced crop growth, development and yield ${ }^{[18]}$, whence this study, aiming to improve wheat yield and yield parameters trough Characterization of adapted variety, has been carried out in cold region ofMugamba at Mwaro province in Burundi country.

\section{MATERIALS AND METHODS}

\section{2.1 Site Description and experiment design}

The experimental site was located in Mugamba region at Mwaro, in the Agricultural Sciences Institute of Burundi (ISABU) at Gisozi with an altitude ranged between 2120 and $2175 \mathrm{~m}$. The yearly precipitation was about $1503.2 \mathrm{~mm}$, with a monthly average temperature of $21.8^{\circ}$. The soil is humus kaolisol type with a dark and humic horizon according to the regional classification published in 1995 by the Agricultural Sciences Institute of Burundi. It is an acid soil, with very low soil nutrients content characteristic of mugamba south natural region.

The experiment was carried out in blocks completely randomized with four replications. It has considered 6 varieties which areBW 388; 21 SAWYT308; 21 SAWYT323; 21 SAWYT334; 21 SAWYT338 and 21 SAWYT349. For fertilization, the organo mineral fertilizers were used with DAP (130); urea $(80 \mathrm{~kg})$ and $\mathrm{Kcl}(50 \mathrm{Kg})$. However an additional application of urea $(90 \mathrm{~kg} / \mathrm{ha})$ was done at tillering period and after weeding. Moreover, during the experiment, pest and diseases were controled with pesticides and fongicides application.

\subsection{Data sampling}

During growth, plant heigh, leaf area index and flowers number were recorded. At maturity, data on grain number, grains weight and plant yield were assessed after oven-drying at $100^{\circ} \mathrm{C}$ to constant weight.

\subsection{Statistical analysis}

Data statistical analysis was done through Genstat Discovery Edition 4 and advanced Excel. Comparisons between treatments were conducted using Student-Newman-Keuls test at 5\%, while Excel was used for figures and tables. 


\section{RESULTS}

\subsection{Analysis of plant heigth}

Heightis a major parameter that can be used not only as an indicator of overall plant growth vigor, but also to estimate other crop traits ${ }^{[4-5]}$. In this study, plant height has been tested and analysed as can be seen in Figure1.

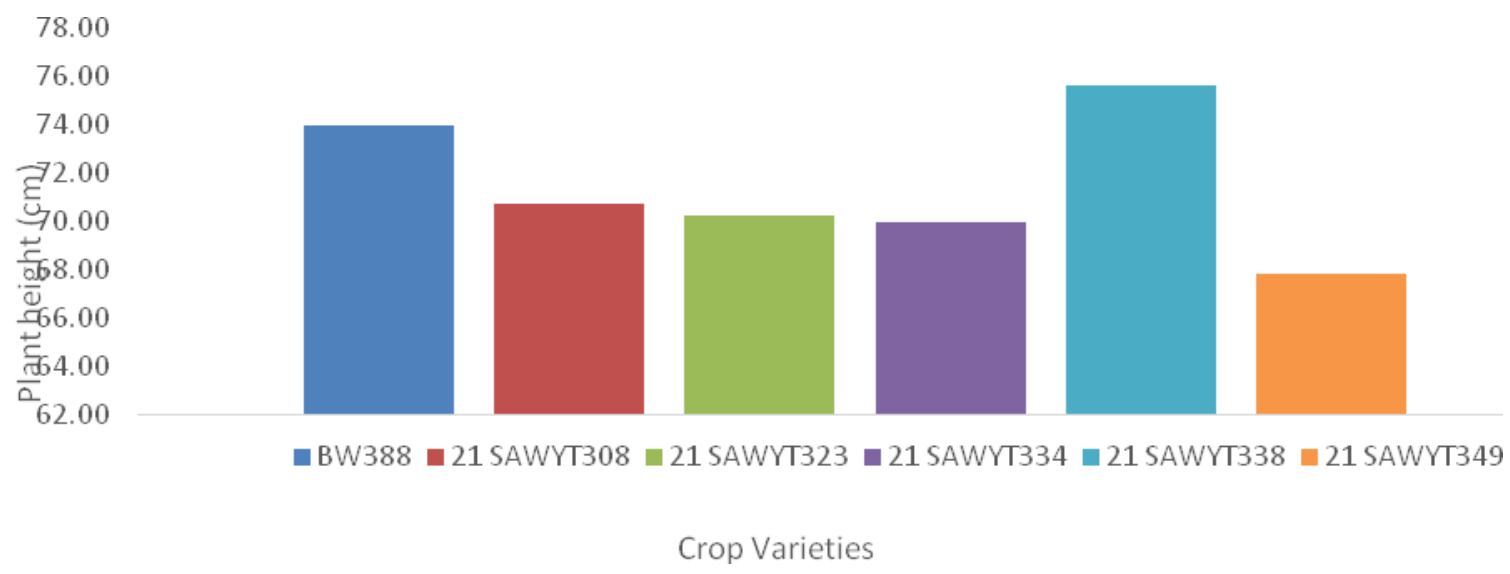

Figure 1. Analysis of plant height $(\mathrm{PH})$

Outcomes onplant height displayed in figure 1 showed highest PH for variety 21SAWYT338 with $75.67 \mathrm{~cm}$.It significantly differed from variety 21 SAWYT349 for which shortest plant of $67.83 \mathrm{~cm}$ was recorded. However variety 21SAWYT338 did not significantly differed from the control BW388 with plant height of $74 \mathrm{~cm}$.

\subsection{Analysis of heading date}

The heading date is the time node that marks the transition from vegetative growth toreproductive growth ${ }^{[21]}$, whence accurately monitoring the heading dates of wheat is of great significance. The following figure 2 synthesizes the results. 


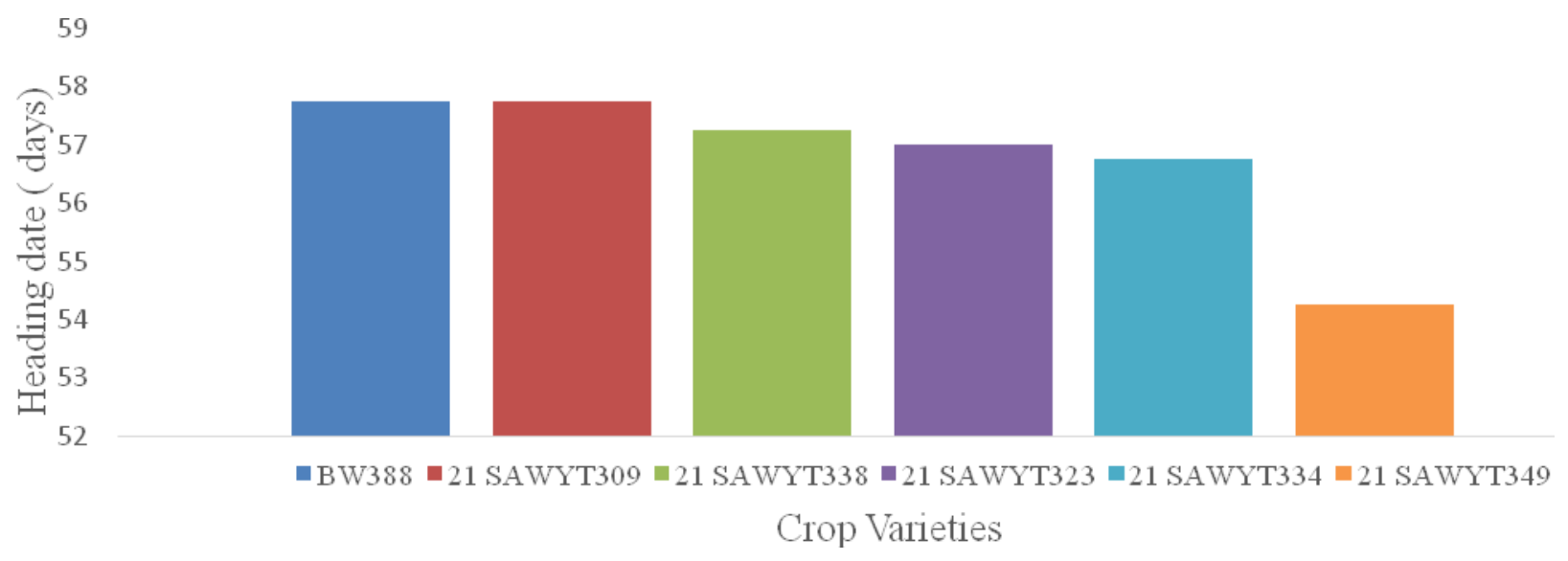

Figure 2. Assessment of plant heading date

For heading date, the variety 21SAWYT349 with 54 days was the earlier variety comparatively to others. It showed significant difference from others with probability value $p<0.05$. The second earlier plants were 21SAWYT338, 21SAWYT323 and 21SAWYT334 which recorded the same value of 57 days. The long heading period was observed for varieties 21SAWYT308 and the control BW338 with 58 days.

\subsection{Plant maturity date analysis}

Maturity date is very important due to crop harvested too early may lack flavour and may not ripen properly, while produce harvested too late may be fibrous or have very limited market life. However a crop can be mature earlier and has all the qualities if other tested growth parameters and production have been also improved for this crop. Maturity date is a parameterthat farmers can use in planning sowing date to haverst at a proper stage which is of paramount importance for attaining desirable quality. Furthermore, maturity inquire about the selection of storage methods, and selection of processing operations for value addition ${ }^{[22]}$. Relate results were shown in figure 3 


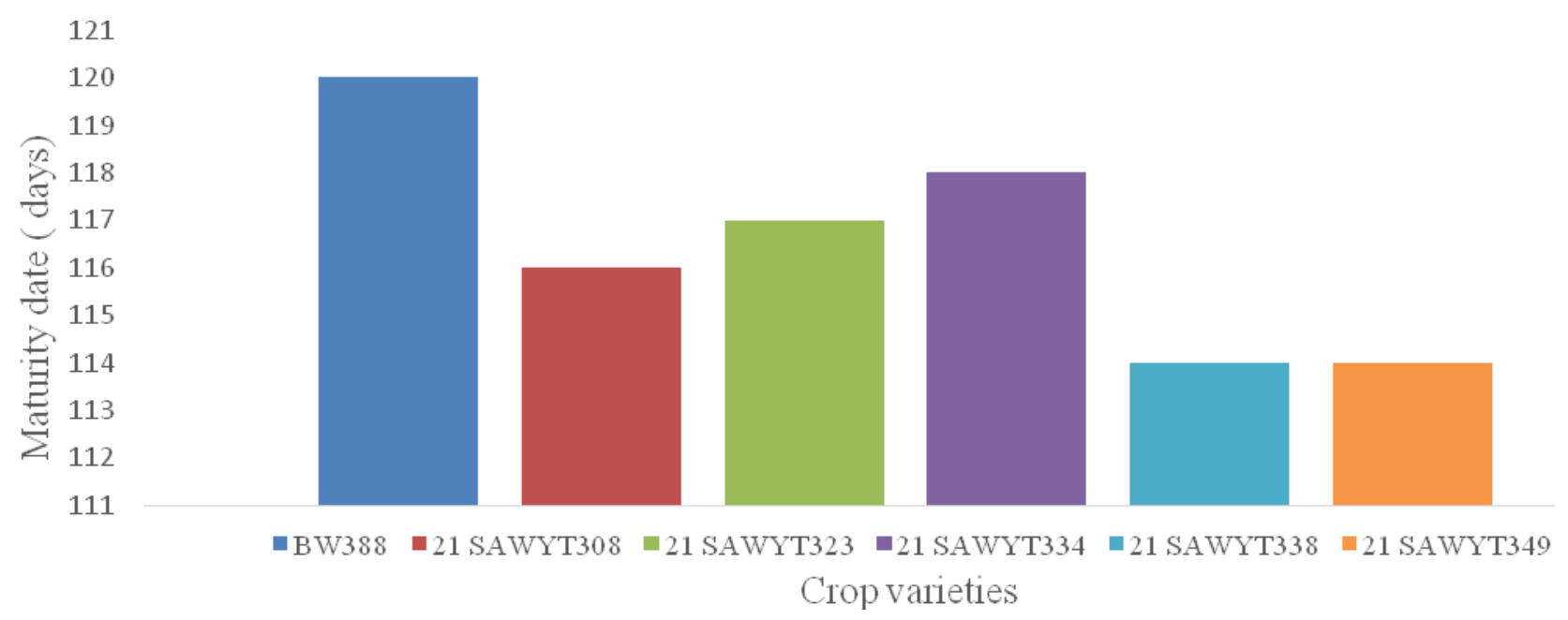

Figure 3. Maturity date evaluation

Thematurity date of 114 days recorded for both varieties 21SAWYT338 and 21SAWYT349 was the ealier date comparatively to others. These varieties significantly differed to the control which was the later harvested variety with 120 days for maturity. For others : 21SAWYT308, 21SAWYT323 and 21SAWYT334, littler discrepancy was noticed with $116 ; 117$ and 118 days formaturity daterespectively and did not significantly differed to the control.

\subsection{Plant grains number assessment}

Number of grains is an important yield component ofwheat. Usually the number of grains per spike isdetermined at panicle primordial formation stage whichdepends on both genetic as well as management factors as reaveled by Schwarte et al. $(2006)^{[23]}$. Figure 4 gives the details for this parameters. 


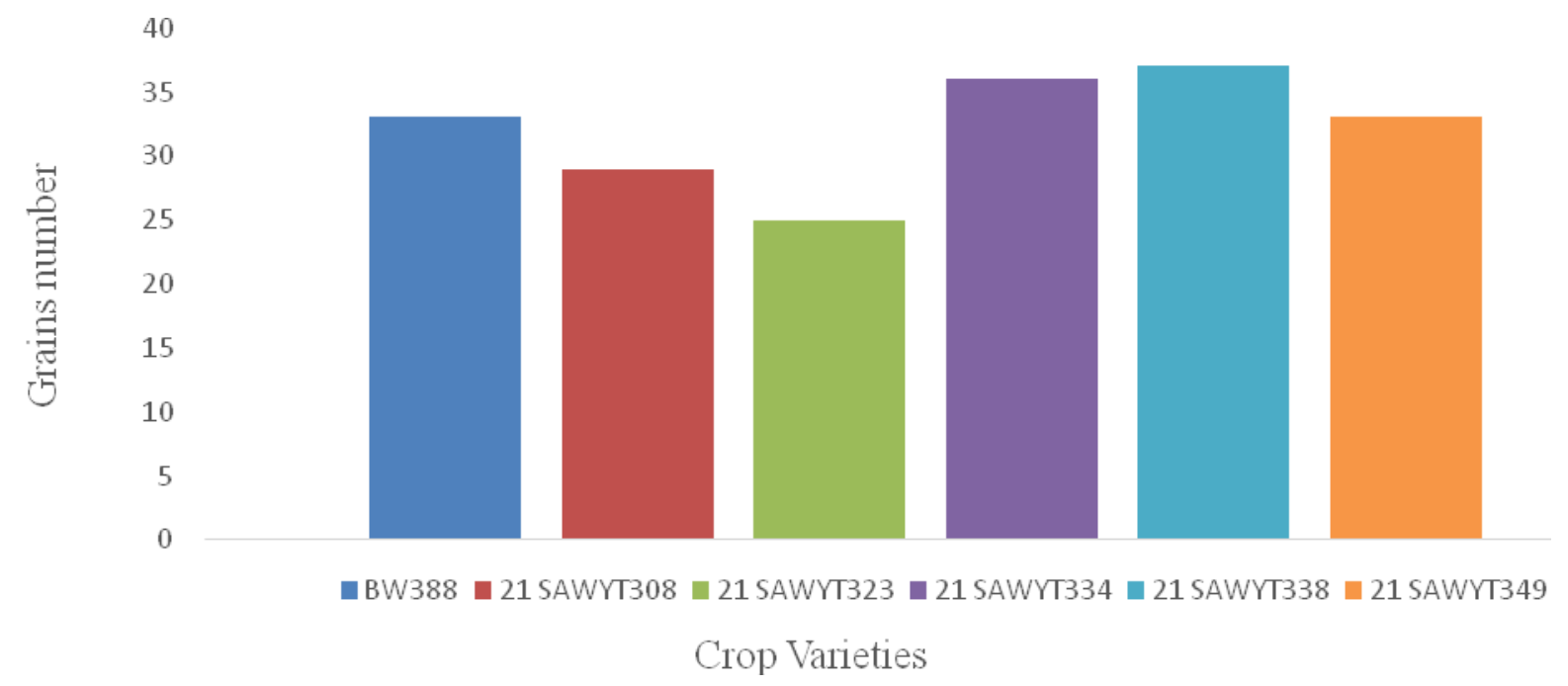

Figure 4. Grains number analysis

Through this table 1, although non significant difference was not observed for this parameter, recorded values differ from variety to an other. Specifically, variety 21ASWYT338 recorded optimum grains number of 37 per plant, followed by 21ASWYT 334 with the secong higher value of 36 grains per plant. The lowest value of 25 was observed for 21SAWYT 323.

\subsection{Plant Thousand grains weight analysis}

Assessment of thousand grains weight is a major focus especially for wheat, a key crop for aged people. Thousand grain weight represents the average value of individual grain weight ${ }^{[15]}$. Relate outcomes were shown in figure 5.
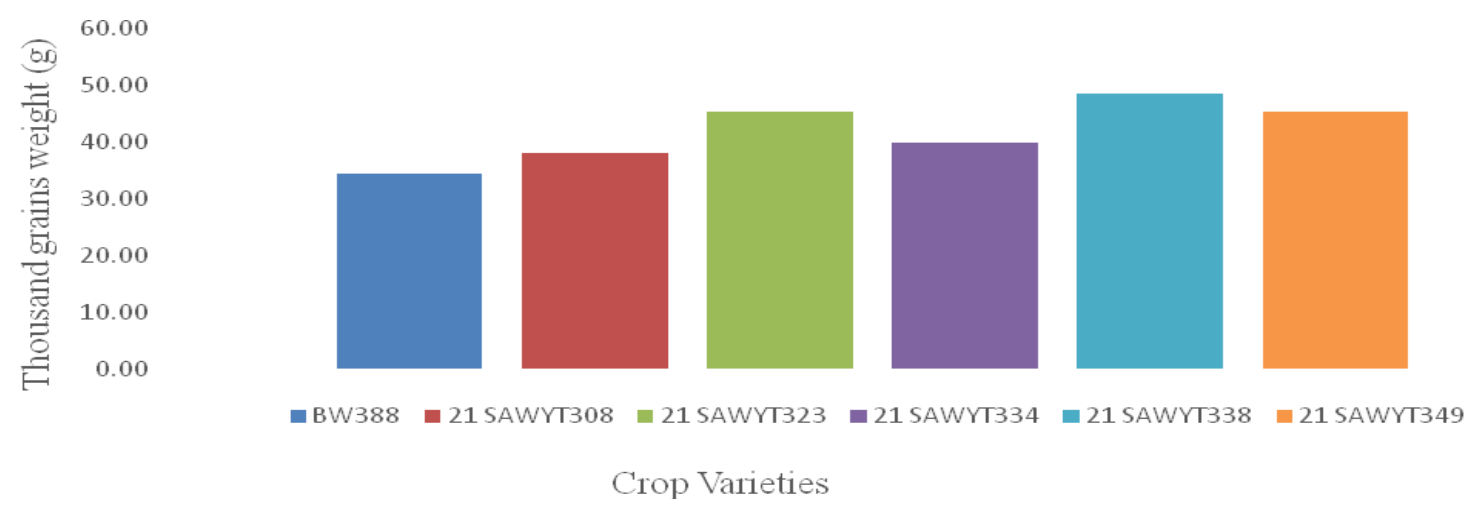

Figure 5. Analysis of thousand grains weight

Considering figure 5, the 21SAWYT 338 recorded the highest value of $48.5 \mathrm{~g}$, followed by 21ASWYT 323 and 21ASWYT 349 with $45.5 \mathrm{~g}$ for both varieties. The minimum was recorded for the control BW338 with $34.5 \mathrm{~g}$. 
Vol. 06, No. 02; 2021

ISSN: $2456-8643$

\subsection{Yield}

Yield grain is an important parameter for evaluating the potential of a given variety. It is a key trait that effects grain cultivation, management, and subsequent yield ${ }^{[17-18]}$. Results for the study were shown in figure 6

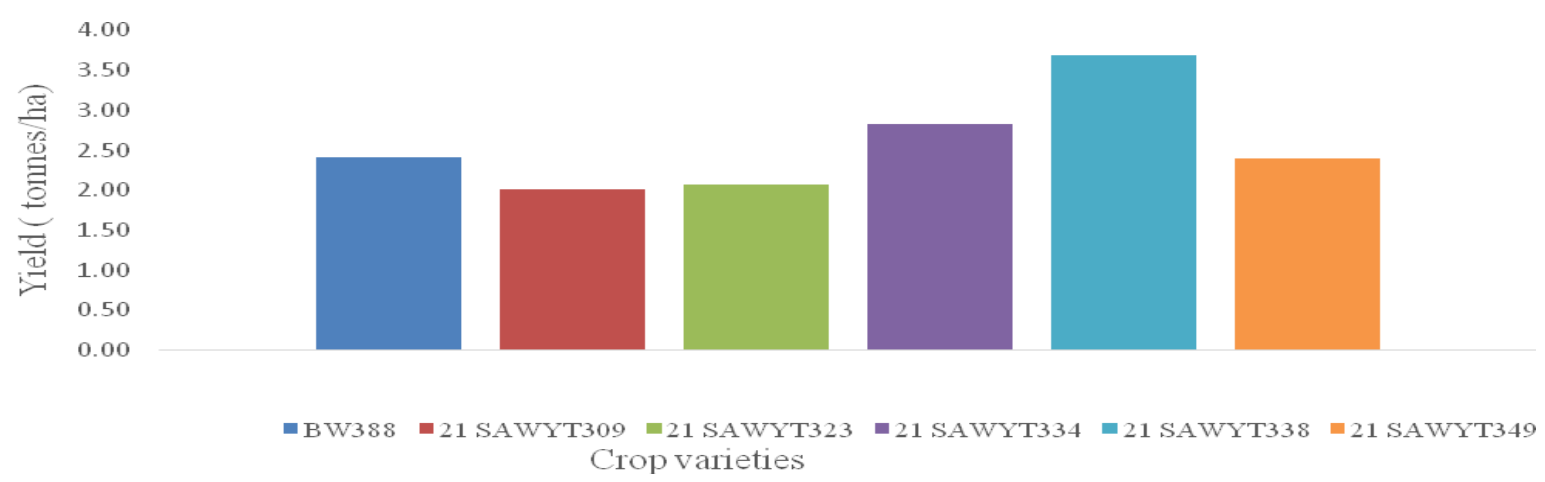

Figure 6. Yield analysis

The outcomes displayed in figure 6 highlighted significant difference between varieties. Clearly, the maximum yield was observed for variety 21ASWYT338of 3.69 tonnes/ha. It significantly differed to the control BW338 of 2.42 tonnes/ha, the third highest value after variety 21ASWYT334 which showed the second highest value of 2.83tonnes/ha. The minimum was observed for variety 21ASWYT 309 and 21ASWYT323 with 2.02 and 2.08 tonnes/ha respectively.

\section{DISCUSSION}

Outcomes of the study showed 21SAWYT338 as the most adapted variety than others. It has shown significant difference for all tested parameters except for heading date where the earlier was 21 ASWYT 349 but the difference was not significative. The improved plant height observed for 21SAWYT338 variety was due to its more adaptation to the ecological condition of the region so that it can assimilate higher nutrientsrequired for it growth and development especially nitrogen as reported by Jan and Khan (2002) who highlighted enhanced wheat growth due to higher nitrogen rate uptaken ${ }^{[26]}$. Similar results for vegetative attributes of wheat were reported by Ullah et al. (2013) ${ }^{[27]}$. Furthermore, the improvement of crop height could be attributed to cell elongation rate since cell division is restricted to a small portion of the shoots and roots as revealed by Miyoshi Haruta and Michael R. Sussman ${ }^{[28]}$. Moreover, this variety 21 SAWYT338 has recorded enhanced yield and its attributes like grains number, thousand grains weight and yield. This could be attributed to the condicive environmentwhich can foster the nutrients assimilation for the variety leading to healthy and productive crop. Singh and Sharma (2001) also found that wheat grain yield and yield-attributing parameters were significantly affected by nutrients uptaken ${ }^{[29]}$. The ealier maturity date recorded for the mentionned variety 21SAWYT338 is more valuable due to that farmers can get their production earlier comparatively to other whence they can sell a part of the haverst to buy supplement food nutrition leading to improved food security. 


\section{CONCLUSION}

Results of the study showed 21SAWYT338 variety as the most adapted variety in the region. It showed improved plant height and yield attributes. Moreover, this variety 21 SAWYT338 has recorded an ealier maturity date which is valuable for household especially during the food lean season where they can sell a part of the haverst to buy supplement food nutrition leading to improved food security. This study suggested 21SAWYT338 variety as the most adapted variety that can be recommended to the farmer of the region.

\section{REFERENCES}

[1]Bhattacharyya BK. Response to applied potassium in important crops and cropping systems in West Bengal. India: Workshop Proc PPIC-IP; 2000. p. 55-60.

[2] Singh J, Sharma HL, Singh CM. Effect of levels and phases of potassium application on growth and yield of rice and wheat. J Pot Res. 2000;16(1-4):35-40.

[3] H.J. Braun, G. Atlin, T. Payne. Multi-location testing as a tool to identify plant response to global climate change M.P. Reynolds (Ed.), Climate change and crop production, Center for Agriculture and Biosciences International, Wallingford (2010), pp. 115-138

[4]Cakmak I. Enrichment of cereal grains with zinc: Agronomic or genetic biofortification? Plant Soil. 2008;302(1):1-17.

[5] Pfeiffer WH, B Mc Clafferty. Harvest plus: Breeding crops for better nutrition. Crop Sci. 2007;47(3):88-105

[6] Cooke RJ, Law JR (1998). Seed storage protein diversity in wheat varieties. Plant Varieties and Seeds. 11: 159-167

[7]Kalnina ST, Rakcejeva, Gramatina I, et al. Investigation of total dietary fiber, vitamin B1 and B2 content in whole-grain pasta. Baltic conference on food science and technology; USA: Fundamental library of the Latvia University of Agriculture; 2014. p. 133-137.

[8] Khalil, I.A. and A. Jan, 2002. Cereal crops. In: Cropping Technology. A text book of Agriculture. New Million Edition. National Book Foundation, Islamabad,Pages: 169

[9] Rengel Z, Batten GD, Crowley DE. Agronomic approaches for improving the micronutrient density in edible portions of field crops. Field Crops Res. 1999;60:27-40

[10] Hao MD, Wei XR, TH Dang. Effect of long-term applying zinc fertilizer on wheat yield and zinc absorption by wheat in dryland. Ecol Environ Sci. 2003;12(1):46-48

[11] https://www.lybrate.com/topic/wheat-benefits. Retrieved on the $2^{\text {nd }}$ March 2021

[12] Boyer J.S. . Plant productivity and environmentScience, 218 (4571) (1982), pp. 443-448

[13] K. Zaynali Nezhad, W.E. Weber, M.S. Röder, S. Sharma, U. Lohwasser, R.C. Meyer,et al. QTL analysis for thousand-grain weight under terminal drought stress in bread wheat (Triticum aestivum L.)Euphytica, 186 (1) (2012), pp. 127-138

[14] D. Byerlee, M. Morris. Research for marginal environments: are we underinvested?Food Policy, 18 (5) (1993), pp. 381-393

[15] Senthold Asseng, Ian Foster and Neil Turner. The impact of temperature variability on wheat yields. May 2010, Global Change Biology, 17(2):997 - 1012. 
Vol. 06, No. 02; 2021

ISSN: $2456-8643$

[16] Senthold Asseng, Frank Ewert, Pierre Martre, and Reimund Pauld Rötter. Rising temperatures reduce global wheat production. February 2015, Nature Climate Change, 5(2):143147.

[17]Modarresi M., Mohammadi V., Zali A. and Mardi M. Response of Wheat Yield and Yield Related Traits to High Temperature. Cereal Research Communications, Vol. 38, No. 1 (March 2010), pp. 23-31

[18] Porter, J.R.; Gawith, M. Temperatures and the growth and development of wheat: A review. Eur. J. Agron.1999, 10, 23-36

[19] [4] https://www.healthbenefitstimes.com/rice-bran/.Retreaved on the 13rd January 2021

[20] Nownze KF, Mohapatra S, Kmawa P, Keya S, Bruce-Oliver S (2006). Rice development in sub-Saharan African Journal of Science Food Agric. 86 : 675-677.

[21] Chu, L.; Huang, C.; Liu, Q.S.; Liu, G.H. Estimation of winter wheat phenology under the influence of cumulative temperature and soil salinity in the Yellow River Delta, China, using MODIS time-series data. Int. J. Remote Sens. 2016, 37, 2211-2232

[22] Wardlaw, Kitinoja, L and Gorny, J. (1998) Post-harvest technology for fruits and vegetables Produce marketers: Economic opportunities. Quality and Food Safety by, Department of Pomology, University of California, Davis. A joint publication of UC Post harvest Outreach Program and Punjab Horticultural Post harvest technology Centre, USAID/ACE

[23] Schwarte, A.J., L.R. Gibson, D.L. Karlen, P.M. Dixon, M. Lieman and J.L. Jannink, 2006. Planting date effects on winter triticale yield and yield components. Crop Sci., 46: 1218-1224.

[24] Sharma D. L., Shackley B. J, Amjad M., Zaicou-Kunesch C. M., D’Antuono M. F., and Anderson W. K. 2009. "Use of Grain Size Distribution Parameters to Explain Variation in Small Grain Screenings of Wheat in Multi-Environment Trials Involving New Cultivars." Crop \& Pasture Science

[25] Garcia GA, Serrago RA, Dreccer MF, Miralles DJ. Post-anthesis warm nights reduce grain weight in field-grown wheat and barley. Field Crop Res. 2016;195: 50 - 59

[26] Slafer GA, Savin R, Sadras VO. Coarse and fine regulation of wheat yield components in response to genotype and environment. Field Crop Res. 2014;157:71-83

[27] Jan, M.T. and S. Khan, 2002. Response of wheat yield components to type of N fertilizer, their levels and application time. Pak. J. Biol. Sci., 3: 1227-1230

[28] Ullah, G., E.A. Khan, I.U. Awan, M.A. Khan, A.A.Khakwani, M.S. Baloch, Q.U. Khan, M.S. Jilani, K. Wasim, S. Javeria and G. Jilani, 2013. Wheat response to application methods and levels of nitrogen fertilizer: I. Phenology, growth indices and protein content. Pak. J. Nutr., 12: $365-370$

[29] Miyoshi Haruta, Michael R. Sussman, in Current Topics in Developmental Biology, 2017. Protein Kinases in Development and Disease. Science Direct, journals and Books [30] Singh, K.N. and D.P. Sharma, 2001. Response of wheat to nitrogen and potassium in saline soils. Exp.Agric., 37: 417-427. 